SOUZA CRUZ, Álvaro Ricardo de; NOGUEIRA, Bernardo G. B.; SILVA, Diogo Bacha e. Alteridade, differánce e ministério público em tempos de coronavírus. Revista Eletrônica Direito e Política, Programa de Pós-Graduação Stricto Sensu em Ciência Jurídica da UNIVALI, Itajaí, v.16, n.2, $2^{\circ}$ quadrimestre de 2021. Disponível em: www.univali.br/direitoepolitica - ISSN 1980-7791.

\title{
ALTERIDADE, DIFFERÁNCE E MINISTÉRIO PÚBLICO EM TEMPOS DE CORONAVÍRUS
}

\author{
ALTERITY, DIFFERÁNCE AND PUBLIC PROSECUTIONS IN TIMES OF \\ CORONAVIRUS
}

\author{
Álvaro Ricardo de Souza Cruz ${ }^{1}$ \\ Bernardo G. B. Nogueira² \\ Diogo Bacha e Silva³
}

\begin{abstract}
RESUMO
O artigo apresenta a atuação do Ministério Público em meio à pandemia do coronavírus e busca uma reinterpretação dos princípios constitucionais da unidade institucional e independência funcional que estruturam a atuação ministerial na Constituição de 1988. A partir da fenomenologia derridiana, a interpretação fechada dos princípios tanto pode ser considerada como veneno ou remédio para o Estado Democrático de Direito. Então, a saída é para o infinito, o Outro, o Rosto.
\end{abstract}

PALAVRAS-CHAVE: Ministério Público, Unidade institucional, Independência funcional, Estado Democrático de Direito.

\begin{abstract}
The article presents the work of the Prosecution through of the coronavirus pandemic and seeks a reinterpretation of the constitutional principles of institutional unity and functional independence that structure the ministerial performance in the 1988 Constitution. From the Derridian phenomenology, the closed interpretation of the principles can either be considered as poison or remedy for the Democratic Rule of Law. So, the way out is to infinity, the Other, the Face.
\end{abstract}

KEYWORDS: Public Prosecution, Institutional unit, Functional independence, Democratic Rule-of-Law State.

\footnotetext{
${ }^{1}$ Graduado em Ciências Econômicas na PUC/MG e Direito na UFMG; Mestre e Doutor em Direito Constitucional pela UFMG. Pós-Doutor em História, Exerceu a chefia, a PRDC e a Coordenação de diversas Câmaras do MPF. Autor de mais de uma dezena de livros jurídicos. Professor Adjunto III na PUC/MG, lecionando na graduação, mestrado e doutorado. Email: alvaro.sc@terra.com.br.

2 Doutor em Teoria do Direito pela PUC/MG. Mestre em Ciências Jurídico-Filosóficas pela Faculdade de Direito da Universidade de Coimbra. Mediador. Professor da Faculdade Milton Campos. Email: bernardogbn@yahoo.com.br

${ }^{3}$ Doutor em teorias jurídicas contemporâneas pela UFRJ, Mestre em Constitucionalismo e Democracia pela FDSM, Professor e advogado. Email: diogobacha@ig.com.br
} 
SOUZA CRUZ, Álvaro Ricardo de; NOGUEIRA, Bernardo G. B.; SILVA, Diogo Bacha e. Alteridade, differánce e ministério público em tempos de coronavírus. Revista Eletrônica Direito e Política, Programa de Pós-Graduação Stricto Sensu em Ciência Jurídica da UNIVALI, Itajaí, v.16, n.2, $2^{\circ}$ quadrimestre de 2021. Disponível em: www.univali.br/direitoepolitica - ISSN 1980-7791.

\section{INTRODUÇÃO}

Esse é um artigo que, dentro de uma concepção derridiana, aborda os limites, os confins, o próprio fim de uma determinada lógica. A lógica que, desde ao menos a promulgação da Constituição de 1988, permeia a atuação do Ministério Público. Dentre as mais diversas e possíveis desestruturações no campo do direito provocadas pelo coronavírus, há uma certa ressignificação que se deve fazer à atuação do Ministério Público nos parâmetros do Estado Democrático de Direito.

Se é certo que o Ministério Público adquiriu um papel central na defesa do regime democrático na Constituição de 1988, sua proeminência institucional dependerá da legitimidade de sua atuação em prol dos direitos fundamentais e da própria sociedade. Por isso, a centralidade não implica, de per si, que sua luta tenha como termo final a data da promulgação da Constituição, 5 de outubro de 1988.

Assim, o problema central do presente texto é analisar, a partir da crise instalada pela pandemia do coronavírus, em que medida a atuação do Ministério Público deve fornecer respostas institucionais coordenadas ou, ainda, se cada membro do Ministério Público poderá atuar de forma isolada em prol da proteção do Estado Democrático de Direito.

Em regra geral, a dogmática tradicional pensa que a unidade institucional e a independência funcional são categorias estanques e, a depender da situação apresentada, contraditórias, isto é, ou bem o Ministério Público age a partir de um centro decisório único que, no caso, corresponde aos Procuradores-gerais, ou, ainda, cada membro é livre para compreender e interpretar a melhor atuação em prol da defesa do regime democrático.

A pandemia em razão do coronavírus, declarada pela OMS em março de 2020, permite pensar em como a sociedade, o Estado e o direito fornecem respostas para as crises e situações excepcionais. A capacidade que cada sistema político tem para oferecer respostas para problemas sanitários dependerá, por óbvio, do engajamento de suas instituições e dos atores políticos às recomendações de saúde, além da própria vontade de Constituição em seguir ou não os rumos prédeterminados pelo Estado Democrático de Direito. 
SOUZA CRUZ, Álvaro Ricardo de; NOGUEIRA, Bernardo G. B.; SILVA, Diogo Bacha e. Alteridade, differánce e ministério público em tempos de coronavírus. Revista Eletrônica Direito e Política, Programa de Pós-Graduação Stricto Sensu em Ciência Jurídica da UNIVALI, Itajaí, v.16, n.2, $2^{\circ}$ quadrimestre de 2021. Disponível em: www.univali.br/direitoepolitica - ISSN 1980-7791.

Acreditamos que a crença no conhecimento poderá nos fornecer respostas seguras mesmo quando o quadro é de incerteza generalizada. Essa resposta que está sempre porvir. Esse caminho mesmo que nos conduzem as mais diversas respostas para os problemas jurídico-políticos devem se manter aberto ao outro, ao diferente, à differánce. ${ }^{4}$

O artigo presente procura atestar a presença do COVID-19 no cenário jurídico e a atuação do Ministério Público que se faz presente nessa presença. ${ }^{5} \mathrm{Um}$ vírus que chega, que desestabiliza e nos coloca a pensar, que nos obriga a sair da comodidade do pensamento metafísico.

Esse vírus que é também do outro, do diferente, do oriente, da China, do estrangeiro de Lévinas, essa nação que, talvez, nunca esteve sob a influência dos gregos, mas que nos levanta uma responsabilidade em relação a esse estrangeiro, o Rosto e a ética da alteridade como filosofia primeira. Essa nação que nos mostra, platonicamente, que há um caminho entre a ideia e substância. Esse caminho invisível, assim como o vírus, que nos obriga a estar sempre caminhando...caminhando...caminhando em direção ao infinito. ${ }^{6}$ Esse vírus que nos mostra a ausência de anticorpos e de imunidade em relação a sistema políticos

\footnotetext{
${ }^{4} \mathrm{O}$ que está por vir é sempre estruturalmente porvir, de modo que não se deve confundir a vinda do outro (venue) com a sua presença futura (présence). No hiper-real, a realidade é sempre abundante em expectativas. O mundo é o objeto não tanto de nossa percepção, mas de nossas orações e lágrimas. É isto que não deixa o mundo que se apresenta se enrijecer, mantendo-se sempre aberto e passível de revisão, com suas quebras e fendas propiciando aberturas para novos acontecimentos. Isto não arruína e nem destrói o mundo, mas o expõe ao risco do futuro, permitindo que o mundo instigue e seja perturbado pelas expectativas do porvir - a justiça e a hospitalidade, a paz messiânica e o dom, a democracia por vir. (CAPUTO, John. Religion Without Religion: The Prayers and Tears. London: Routledge, 2002, p. 47-48)

5 Propositalmente, o verbo utilizado na frase, o "atestar", serve para demarcar nossos traços derridianos no texto que se desenvolverá. A atestação fere a certeza cartesiana.

${ }^{6} \mathrm{O}$ infinito é essa relação entre o eu e o Outro e não se pode medir, eis que é ela própria que mede nossa finitude: "importa sublinhar que a transcendência do Infinito em relação ao eu que dele está separado e que o pensa, mede, se assim se pode dizer, a sua própria finitude" (LÉVINAS, Emmanuel. Totalidade e infinito. Lisboa: Edições 70, 2000.p. 36). Por ser infinito, é mesmo estrangeiro, exterior à própria pessoa que o pensa: "A noção cartesiana da Idéia de Infinito designa uma relação com um ser que conserva a sua exterioridade total em relação àquele que o pensa" (LÉVINAS, Emmanuel. Totalidade e infinito. Lisboa: Edições 70, 2000.p. 37). O Rosto é a maneira como o outro se apresenta a mim infinizando sempre a idéia finita do outro em mim. Essa relação sem qualquer mediação que totaliza.
} 
SOUZA CRUZ, Álvaro Ricardo de; NOGUEIRA, Bernardo G. B.; SILVA, Diogo Bacha e. Alteridade, differánce e ministério público em tempos de coronavírus. Revista Eletrônica Direito e Política, Programa de Pós-Graduação Stricto Sensu em Ciência Jurídica da UNIVALI, Itajaí, v.16, n.2, $2^{\circ}$ quadrimestre de 2021. Disponível em: www.univali.br/direitoepolitica - ISSN 1980-7791.

autoritários, assim como demonstra que mesmo na democracia estamos sempre à mercê de sua própria autoimunidade?

Será que o Ministério Público é esse vírus? Esse mesmo vírus pelo qual não temos imunidade, anticorpos? Esse vírus que representa a ausência e, ao mesmo tempo, a presença da democracia? Ou o vírus mesmo que destrói a democracia por dentro?

O enfrentamento do vírus demanda dos membros do Ministério Público compreender o papel da instituição dentro do Estado Democrático de Direito e também a relação entre a independência funcional e a unidade institucional que, mormente em momentos de crise, estão em rota de colisão.

Nosso intento gravita em atestar as aporias dessa relação, assim como propor uma leitura derridiana da unidade institucional e independência funcional e ensaiar uma resposta que sabemos impossível, mas que essa mesma impossibilidade é a possibilidade de uma resposta democrática ${ }^{8}$. Essa resposta deverá advir do absolutamente outro, da alteridade incondicional, do Rosto que irrompe com a totalidade e com o fechamento dos significados.

\footnotetext{
7 Porque aquilo a que eu chamo o auto-imunitário não consiste apenas em prejudicar-se ou em arruinar-se, ou mesmo em destruir as suas próprias proteções, em fazê-lo por si mesmo, em suicidar-se ou em ameaçar fazê-lo, mas, mais gravemente e por isso mesmo, em ameaçar o eu [moi] ou o si [soi] , o ego ou o autos, a própria ipseidade, em abalar a imunidade do próprio autos: não apenas auto-comprometer-se [s'auto-entamer], mas em comprometer o autos - e portanto também ipseidade. Não apenas em suicidar-se, mas em comprometer a auto-referencialidade, o si do próprio suicida. A auto-imunidade é mais ou menos suicidaria, mas é ainda mais grave: a autoimunidade ameaça sempre privar o próprio suicídio do seu sentido e da sua suposta integridade. (DERRIDA, Jacques. A escritura e a diferença. Trad. Maria Beatriz M. N. Da Silva, Pedro Leite Lopes e Pérola de Carvalho. São Paulo: Perspectiva, 2009, p. 106)

8 Nesse sentido, haverá sempre duas dimensões a atuarem juntas, uma de promessa, de uma promessa que não se irá cumprir, e o incumprimento dessa promessa que carreia a democracia por vir seria exatamente a chance de cada vez mais democracia, chance de sua perfectibilidade, que seria a outra dimensão que apresenta-se enquanto índice de uma democracia por vir, que para além de uma noção equivocada de democracia futura, o por vir derridiano em sede de democracia estaria mais corretamente percebido se tivermos em conta que o por vir não se resumiria ao futuro, a um seu desdobramento, pois, o amanhã pode sempre ser apenas uma repetição do hoje.
} 
SOUZA CRUZ, Álvaro Ricardo de; NOGUEIRA, Bernardo G. B.; SILVA, Diogo Bacha e. Alteridade, differánce e ministério público em tempos de coronavírus. Revista Eletrônica Direito e Política, Programa de Pós-Graduação Stricto Sensu em Ciência Jurídica da UNIVALI, Itajaí, v.16, n.2, $2^{\circ}$ quadrimestre de 2021. Disponível em: www.univali.br/direitoepolitica - ISSN 1980-7791.

\section{A PANDEMIA DO CORONAVÍrus e A ATUAÇÃo CONTRADITÓRIA do MINISTÉRIO PÚBLICO}

É novembro de 2019 e tal como ocorre todos os dias, Wuhan, capital da província de Hubei, uma cidade com quase 12 milhões de habitantes, tem uma vida normal. Pessoas andam de um lado para o outro, o cotidiano é seguro e fornece uma garantia de "ser" vivo. O trabalho anda a todo vapor. Pessoas acordam cedo, se deslocam ao trabalho, produzem bens e serviços com a sensação de ser "útil" ao próximo, trocam afetos com pessoas próximas, caminham, se exercitam, se alimentam, tudo parece transcorrer de maneira como programada. Futuros são planejados entre os familiares, olhares e carinhos são trocados entre os casais, confraternizações entre os amigos são o ponto em que as pessoas podem se distanciar dos problemas que as assolam cotidianamente, crianças vão às escolas para aprender a sonhar, restaurantes estão cheios e a alimentação é uma dádiva divina para esses corpos insaciáveis.

À margem, portanto, desse cotidiano, um local na qual estabelece uma contradição entre a vida e a morte, Li Wenliang, oftalmologista com apenas 34 (trinta e quatro) anos de idade, alguém que, até então, participa também do cotidiano, está prestes a descobrir aquilo que mudaria o rumo global nas paredes de um Hospital. Alguns poucos indivíduos apresentam sintomas semelhantes de Insuficiência Respiratória Grave.

Do outro lado do Atlântico, no Brasil, a recém-promulgada Lei 13.869/2019 que define os crimes de abuso de autoridade, prestes a entrar em vigor, é motivo de uma disputa narrativa em torno da possível violação da independência dos órgãos de persecução criminal. Neste ponto, por exemplo, os Coordenadores da Câmara de Coordenação e Revisão e a Procuradoria Federal dos Direitos dos Cidadãos do Ministério Público Federal externaram a preocupação com a aprovação da supramencionada lei como sendo um ato normativo que acabaria por enfraquecer a autoridade pública na fiscalização, investigação e persecução de atos ilícitos e na defesa dos direitos fundamentais. ${ }^{9}$ No mês de setembro de 2019, mesmo mês

\footnotetext{
${ }^{9}$ Nota pública do Ministério Público Federal expressando uma "unidade institucional": Disponível em: https://static.poder360.com.br/2019/08/Nota-MPF-PL75962017.pdf, acesso em 15 de abril de 2020.
} 
SOUZA CRUZ, Álvaro Ricardo de; NOGUEIRA, Bernardo G. B.; SILVA, Diogo Bacha e. Alteridade, differánce e ministério público em tempos de coronavírus. Revista Eletrônica Direito e Política, Programa de Pós-Graduação Stricto Sensu em Ciência Jurídica da UNIVALI, Itajaí, v.16, n.2, $2^{\circ}$ quadrimestre de 2021. Disponível em: www.univali.br/direitoepolitica - ISSN 1980-7791.

da promulgação da lei de abuso de autoridade, Augusto Aras é nomeado ao cargo de Procurador-Geral da República pela indicação do Presidente Jair Bolsonaro. Sua nomeação não observou a lista tríplice formada pelo próprio órgão para a chefia da instituição, tradicionalmente observada em desde o governo Lula.

Logo, essas histórias irão se cruzar, pois como sabemos aquilo que acontece na margem da história sempre é capaz de desestabilizar o centro, o cronista deve bem saber que nenhum acontecimento é descartável para a história da humanidade. ${ }^{10} \mathrm{O}$ destino reservará um acontecimento que possibilitará um momento de inflexão em diversas instituições. Essa inflexão é causada por algo que, até então, está à margem do pensamento ocidental, originado na cultura oriental ou, naquilo que o logos construiu como oriente. ${ }^{11}$

Em dezembro, aquelas dezenas de caso de insusficiência respiratória grave se transformaram em centenas, localizados na cidade de Wuhan. Sem conseguir rastrear aquele que seria o "paciente zero" e a origem da doença, as autoridades de saúde da cidade de Wuhan reportam tais casos em 31 de dezembro de 2019 para a OMS - Organização Mundial de Saúde, conseguindo, entretanto, realizar uma sequência do vírus causador de uma nova pneumonia e constatando que se trata de um novo coronavírus.

Em 11 de janeiro de 2020 é anunciada a primeira morte causada pelo coronavírus que, segundo autoridades chineses, teria sido originada no mercado de Wuhan por uma cadeia de transmissão de animais vivos para os humanos (morcego?cobra?pangolim?). Apenas dois dias após o anúncio, é comunicado o primeiro caso fora da China, na Tailândia. A prova que modificará o mundo é a

\footnotetext{
10 Walter Benjamin em sua Tese sobre o conceito de história: "O cronista que narra os acontecimentos, sem distinguir entre os grandes e os pequenos, leva em conta a verdade de que nada do que um dia aconteceu pode ser considerado perdido para a história. Sem dúvida, somente a humanidade redimida poderá apropriarse totalmente do seu passado. Isso quer dizer: somente para a humanidade redimida o passado é citável, em cada um dos seus momentos. Cada momento vivido transforma-se numa citation à l'ordre du jour - e esse dia é justamente o do juízo final" (BENJAMIN, Walter. Sobre o conceito da história. In: Magia, técnica, arte e política: ensaios sobre literatura e história da cultura. $8^{a}$ ed. São Paulo: Brasiliense, 2012. p. 244).

${ }^{11}$ SAID, Edward. Orientalismo: o oriente como invenção do ocidente. Trad. Tomás Rosa Bueno. São Paulo: Companhia das Letras, 1990.
} 
SOUZA CRUZ, Álvaro Ricardo de; NOGUEIRA, Bernardo G. B.; SILVA, Diogo Bacha e. Alteridade, differánce e ministério público em tempos de coronavírus. Revista Eletrônica Direito e Política, Programa de Pós-Graduação Stricto Sensu em Ciência Jurídica da UNIVALI, Itajaí, v.16, n.2, $2^{\circ}$ quadrimestre de 2021. Disponível em: www.univali.br/direitoepolitica - ISSN 1980-7791.

comprovação, em 20 de janeiro, da possibilidade de transmissão entre seres humanos. ${ }^{12}$

Aqui, a iminência da vigência da Lei 13.964/2019, promulgada em dezembro de 2019, popularmente conhecida como Lei anti-crime, que instituiu o juiz de garantias, bem como a tramitação direta da investigação criminal é parte de uma discussão de insurgência dos membros do Ministério Público ao fato de que tal norma atingiria direitos fundamentais dos membros da instituição. ${ }^{13}$

Em 23 de janeiro, a cidade de Wuhan decreta lockdown como forma de combate ao novo tipo de coronavírus. Embora essa cidade de 12 milhões esteja em quarentena, a OMS - Organização Mundial de Saúde nega uma emergência global de saúde, situação que seria modificada apenas alguns dias depois, 27 de janeiro, pela detecção de infecção na Alemanha e Japão de indivíduos que não estiveram no território chinês, decretando um surto de emergência internacional de saúde pública. O Congresso Nacional aprova a Lei 13.979/2020 com medidas para o enfrentamento da emergência internacional de saúde pública do coronavírus em 06 de fevereiro de 2020.

No dia 11 de fevereiro, a OMS decide nomear o novo coronavírus como COVID-19 quando se começa a contabilizar mortes fora do território chinês, inclusive o marco de 15 e 26 de fevereiro, respectivamente, primeira morte em território europeu de um chinês e o primeiro morto europeu. Também no dia 26 de fevereiro, o Brasil registra o primeiro brasileiro infectado pela doença. Enquanto

\footnotetext{
12 Até então o Ocidente não se preocupava com as mortes dos chineses, afinal eles não se alimentavam de morcegos, cobras, pangolins e animais silvestres de toda a espécie. Esse seria um problema daqueles sujeitos que não têm acesso à carnes bovinas, suínas e de peixes e aves. Aqui, portanto, a ausência de preocupação demonstra bem como o Ocidente trata os diferentes.

13 A Associação Nacional dos Membros do Ministério Público-CONAMP ajuizou Ação Direta de Inconstitucionalidade perante o Supremo Tribunal Federal, ADI 6305, cujo relator Min. Luiz Fux concedeu o pedido liminar para que prorrogasse a vacatio legis para a implantação do juiz de garantia. O Ministro concedeu a cautelar em decisão monocrática para suspender a eficácia de diversos dos dispositivos impugnados "Medidas cautelares concedidas para suspender sine die a eficácia: (a) Da implantação do juiz das garantias e seus consectários (Artigos $3^{\circ}-\mathrm{A}, 3^{\circ}-\mathrm{B}, 3^{\circ}-\mathrm{C}, 3^{\circ}-$ $D, 3^{a}-E, 3^{0}-F$, do Código de Processo Penal) (b) Da alteração do juiz sentenciante que conheceu de prova declarada inadmissível (157, §50, do Código de Processo Penal); (c) Da alteração do procedimento de arquivamento do inquérito policial (28, caput, Código de Processo Penal); e (d) Da liberalização da prisão pela não realização da audiência de custodia no prazo de 24 horas (Artigo $310, \S 4^{\circ}$, do

Código de Processo Penal)" (STF, ADI 6305/DF, rel. Min. Luiz Fux, decisão monocrática de 22 de janeiro de 2020).
} 
SOUZA CRUZ, Álvaro Ricardo de; NOGUEIRA, Bernardo G. B.; SILVA, Diogo Bacha e. Alteridade, differánce e ministério público em tempos de coronavírus. Revista Eletrônica Direito e Política, Programa de Pós-Graduação Stricto Sensu em Ciência Jurídica da UNIVALI, Itajaí, v.16, n.2, $2^{\circ}$ quadrimestre de 2021. Disponível em: www.univali.br/direitoepolitica - ISSN 1980-7791.

isso, a própria OMS reconhece que o mundo não está pronto para lidar com a emergência de saúde pública.

O alerta, então, de uma epidemia sobe para muito elevada por declaração da OMS de 28 de fevereiro em conjunto com as medidas preventivas. A Europa começa a cancelar eventos esportivos e de lazer com aglomerações de pessoas. No começo de março, a rápida expansão dos casos, faz com que a maioria dos países europeus decretem quarentena e isolamento social.

No Brasil, o dia 11 de março é o início daquilo da desestabilização do cotidiano com a decretação da pandemia em razão do COVID-19 pela OMS Organização Mundial da Saúde e, por conseguinte, os Estados começam a autonomamente enfrentar os dilemas da emergência sanitária com a decretação da quarentena, sendo o Distrito Federal o primeiro Estado a determinar a quarentena, isolamento social, suspensão das aulas nas redes de ensino, pública e privada, além de atendimento ao público em comércios. Ações similares foram tomadas nos Estados de São Paulo e Rio de Janeiro no dia seguinte, a exceção que tende a se transformar na normalização.

Após alguns dias, várias cidades começaram a decretar quarentena nos limites de seus municípios, atendendo a recomendação das autoridades sanitárias e de acordo com a Lei 13.979/2020, seguindo os ditames do governo estadual, assim como definindo as atividades essenciais que poderão funcionar no período.

Indo na contramão das entidades regionais e locais, o governo federal, por meio de seu Presidente e contrariando até mesmo o Ministério da Saúde, cuja comitiva que viajou aos Estados Unidos da América apresentou mais de 20 infectados do coronavírus, inclusive uma suspeita sobre o Presidente Bolsonaro depois que seu primeiro exame foi positivo, passa a publicamente minimizar os efeitos da pandemia. Taxando-a de simples "gripezinha", pregando que alguns fatalmente iriam sucumbir e que não poderia o país parar por causa de alguns "velhinhos". Simbolicamente, o Presidente Bolsonaro passa a desrespeitar publicamente a quarentena, indo de encontro com seguidores. 
SOUZA CRUZ, Álvaro Ricardo de; NOGUEIRA, Bernardo G. B.; SILVA, Diogo Bacha e. Alteridade, differánce e ministério público em tempos de coronavírus. Revista Eletrônica Direito e Política, Programa de Pós-Graduação Stricto Sensu em Ciência Jurídica da UNIVALI, Itajaí, v.16, n.2, $2^{\circ}$ quadrimestre de 2021. Disponível em: www.univali.br/direitoepolitica - ISSN 1980-7791.

A incapacidade de lidar com os problemas econômicos e sociais, fazem com que o governo federal desdenha da pandemia, contrariando todo o planeta, e uma aposta total em prol do medicamente "cloroquina" que, em ensaios clínicos, demonstram pouca eficácia contra o coronavírus.

Politicamente, tanto o Congresso Nacional quanto o Supremo Tribunal Federal se afastam de Bolsonaro e passam a confiar no Ministro da Saúde, assim como os Governadores estabelecem diálogo apenas com o Min. Luiz Mandettta que passa a ser atacado publicamente pelo Presidente Bolsonaro. Basicamente, o Presidente da República após o evento em que, mesmo à sombra do coronavírus por ter testado positivo, saúda os seus fiéis seguidores na porta do Palácio do Planalto, perde a capacidade de governar, transformando o presidencialismo em um parlamentarismo na qual as políticas são todas executadas pelo Congresso Nacional sem um diálogo com o Poder Executivo.

Neste cenário, ao invés de uma união nacional para o combate do mesmo inimigo, cada autoridade, na ausência de uma liderança política nacional, passa a agir sozinha. Cada Estado e Município adotam práticas de acordo com suas Secretarias de Saúde e Comitês Científicos. O país se desfaz em pequenos feudos que, à moda da idade média, constroem muros/limites físicos para impedir a entrada de indivíduos com o medo de transmissão do coronavírus.

O Ministério Público em meio a esse cenário de incerteza e de desunião das autoridades públicas em níveis federal, estadual e municipal passa a atuar de forma contraditória e, quiçá, como um espelho dessas próprias autoridades. Em níveis regionais, os Ministérios Públicos Federal e Estadual atuam em conjunto realizando recomendações em face de decretos municipais que, de modo ou outro, acabam por abusar do poder estabelecendo barreiras físicas e não barreiras sanitárias. Além do mais, o Ministério Público busca atuar na destinação de recursos públicos para o enfrentamento das pandemias em fundos de combate aos crimes de diversas naturezas. Cada órgão local, portanto, busca reforçar o combate da pandemia atuando de forma independente.

Vale mencionar que a atuação do Ministério Público tem se valido das recomendações que têm natureza jurídica de atuação extrajudicial do Ministério 
SOUZA CRUZ, Álvaro Ricardo de; NOGUEIRA, Bernardo G. B.; SILVA, Diogo Bacha e. Alteridade, differánce e ministério público em tempos de coronavírus. Revista Eletrônica Direito e Política, Programa de Pós-Graduação Stricto Sensu em Ciência Jurídica da UNIVALI, Itajaí, v.16, n.2, $2^{\circ}$ quadrimestre de 2021. Disponível em: www.univali.br/direitoepolitica - ISSN 1980-7791.

Público pelo qual o órgão busca persuadir, em ato formal, o destinatário a realizar atos ou abster-se de o praticar em virtude do interesse público. ${ }^{14}$

Contudo, as medidas direcionadas aos órgãos da Administração Pública Direta da União e que, de alguma forma, contrariem os interesses do governo federal sofrem uma atuação direta de blindagem do Procurador-Geral da República que passa a centralizar todas as recomendações, inclusive arquivando notíciacrime contra o Presidente da República em virtude do desrespeito à quarentena com o teste positivo, tendo cometido, em tese, o delito do art. 268 do Código Penal.

De um lado, portanto, a independência funcional e a atuação do Ministério Público corroborando o acerto das medidas de isolamento das entidades regionais e locais, de outro a unidade institucional provocando uma afirmação do acerto da atuação do governo federal.

Essa pandemia, ao menos em nosso território, expõem uma relação estranha das instituições em que falam mais de uma língua (plus d'une langue) no sentido derridiano. Essa relação, entretanto, marca uma contradição: não deve a Instituição estar estabelecida dentro de uma lei, dentro de uma própria Instituição. ${ }^{15}$ Qual a lei, então, do Ministério Público?

\section{A independência funcional e a unidade institucional em uma perspectiva do Estado Democrático de Direito.}

\footnotetext{
${ }^{14}$ A recomendação vem regulamentada na Resolução do CNMP no 164/17:

"Art. $1^{\circ} \mathrm{A}$ recomendação é instrumento de atuação extrajudicial do Ministério Público por intermédio do qual este expõe, em ato formal, razões fáticas e jurídicas sobre determinada questão, com o objetivo de persuadir o destinatário a praticar ou deixar de praticar determinados atos em benefício da melhoria dos serviços públicos e de relevância pública ou do respeito aos interesses, direitos e bens defendidos pela instituição, atuando, assim, como instrumento de prevenção de responsabilidades ou correção de condutas.

Parágrafo único. Por depender do convencimento decorrente de sua fundamentação para ser atendida e, assim, alcançar sua plena eficácia, a recomendação não tem caráter coercitivo".

15 DERRIDA, Jacques. Essa estranha instituição chamada literatura. Belo Horizonte: Editora UFMG, 2014.
} 
SOUZA CRUZ, Álvaro Ricardo de; NOGUEIRA, Bernardo G. B.; SILVA, Diogo Bacha e. Alteridade, differánce e ministério público em tempos de coronavírus. Revista Eletrônica Direito e Política, Programa de Pós-Graduação Stricto Sensu em Ciência Jurídica da UNIVALI, Itajaí, v.16, n.2, $2^{\circ}$ quadrimestre de 2021. Disponível em: www.univali.br/direitoepolitica - ISSN 1980-7791.

O Ministério Público Francês nasce como uma simbiose entre os advogados do rei (avocats du roi) com funções exclusivamente cíveis e os procuradores do rei (procureurs du roi) com funções de natureza criminal ao lado da função do fisco nas primeiras monarquias. ${ }^{16}$ Seu nascimento é relacionado ao Estado moderno, ao leviatã, ao soberano, bastando ver que seus órgãos não atuam no chão, mas sim de cima do mesmo estrado (parquet) em que eram colocadas as cadeiras do magistrado.

No Brasil, embora houvessem referências aos promotores na Ordenações Filipinas e Manuelinas previam a figura do promotor com nítida inspiração francesa para a fiscalização da lei e da justiça, além de promover a acusação criminal, a sistematização das funções do promotor adveio com o Código de Processo Criminal do Império como órgão da sociedade e titular da ação penal, nomeado pelo governo das cortes ou presidente da província dentre os jurados que sabiam as leis (art. 36). ${ }^{17}$

Sua previsão normativa como instituição ganha algumas linhas com o Decreto 848/1890 que regulamentava a Justiça Federal. No plano infraconstitucional, portanto, as funções do Ministério Público não eram substancialmente alteradas. Prevendo a figura do Procurador-Geral da República, escolhido dentre os membros do Supremo Tribunal Federal, e um cargo de Procurador Federal em cada seção da justiça federal, nomeados pelo Presidente da República, deveriam propor as ações penais e zelar pela observação das leis (arts. 21 a 26). ${ }^{18}$

\footnotetext{
16 MACEDO JÚNIOR, Ronaldo Porto. A evolução institucional do ministério público brasileiro. In: SADEK, Maria Tereza (org.). Uma introdução ao estudo da justiça. Rio de Janeiro: Centro Edelstein de Pesquisas Sociais, p. 65-94, 2010. Disponível em: https://goo.gl/xw5DiR. acesso em 18 de abril de 2020.

17 MACHADO, Antônio Claudio da Cost. A intervenção do Ministério Público no processo civil. São Paulo: Ed. Saraiva, 1989. p. 17-18.

18 Diz a exposição de motivos do Min. Campos Salles: "O ministerio publico, instituição necessaria em toda a organização democratica e imposta pelas boas normas da justiça, está representado nas duas espheras da Justiça Federal. Depois do Procurador Geral da Republica, vêm os procuradores seccionaes, isto é, um em cada Estado. Compete-Ihe em geral velar pela execução das leis, decretos e regulamentos que devam ser applicados pela Justiça Federal e promover a acção publica onde ella couber. A sua independencia foi devidamente resguardada" (BRASIL. Exposição de motivos ao Decreto n. 848, de 11 de outubro de 1890. Organiza a justiça federal. Decretos do Governo Provisório da República dos Estados Unidos do Brasil, Rio de Janeiro, décimo fascículo, p. 2744-2791, 1890).
} 
SOUZA CRUZ, Álvaro Ricardo de; NOGUEIRA, Bernardo G. B.; SILVA, Diogo Bacha e. Alteridade, differánce e ministério público em tempos de coronavírus. Revista Eletrônica Direito e Política, Programa de Pós-Graduação Stricto Sensu em Ciência Jurídica da UNIVALI, Itajaí, v.16, n.2, $2^{\circ}$ quadrimestre de 2021. Disponível em: www.univali.br/direitoepolitica - ISSN 1980-7791.

Inspirado na tradição francesa, havia uma certa tendência legislativa de considerar os membros do Ministério Público como magistrados. Não é à toa, por exemplo, que a Constituição de 1891 nada dispõe acerca do órgão, fazendo referência ao Procurador-Geral da República ao tratar da competência do Poder Judiciário.

O advento da República e os diversos diplomas legais, tais como o Código Civil de 1917, o Código de Processo Civil de 1939, o Código Penal de 1940 e o de Processo Penal de 1941 estabeleceram atribuições ao Ministério Público que, embora não estivessem previstas na Constituição, conferiam um caráter institucional, tal como a curadoria das fundações, a defesa dos interesses dos menores e legitimidade para a interdição no Código Civil; a função de custos legis para a defesa dos valores centrais de uma sociedade agrária no CPC de 1939, dando início ao que a doutrina caracterizará como práxis jurídica do parecerismo; a titularidade da ação penal e a possibilidade de requisição de inquérito policial no CPP. ${ }^{19}$

Não sem razão, a Constituição de 1946 foi a primeira a dedicar um capítulo específico para o Ministério Público em que delimitava a organização por meio de lei (art. 125), a escolha do Procurador-Geral da República como chefe do Ministério Público Federal por escolha do Presidente da República e aprovação do Senado Federal (art. 126), além da organização em carreira cujo ingresso dar-se-á por meio de concurso público (art. 127). Por último, adotando uma simetria com o modelo de Estado federativo, a previsão de Ministério Público no âmbito dos Estados (art. 128).

Por óbvio, há uma ligação intrínseca entre a institucionalização do Ministério Público e a Constituição democrática de 1946 que, no entanto, teve vida curta em nossa história constitucional. Historicamente, portanto, o Ministério Público tem uma forte ligação com a democracia, sendo fortalecido nos períodos democráticos e oprimido nos períodos autoritários. Embora se tenha uma fisionomia de um órgão de Estado, sua estrutura espelha bem o modelo de Estado do qual integra.

19 MACEDO JÚNIOR, Ronaldo Porto. A evolução institucional do ministério público brasileiro. In: SADEK, Maria Tereza (org.). Uma introdução ao estudo da justiça. Rio de Janeiro: Centro Edelstein de Pesquisas Sociais, p. 65-94, 2010. Disponível em: https://goo.gl/xw5DiR. acesso em 18 de abril de 2020. 
SOUZA CRUZ, Álvaro Ricardo de; NOGUEIRA, Bernardo G. B.; SILVA, Diogo Bacha e. Alteridade, differánce e ministério público em tempos de coronavírus. Revista Eletrônica Direito e Política, Programa de Pós-Graduação Stricto Sensu em Ciência Jurídica da UNIVALI, Itajaí, v.16, n.2, $2^{\circ}$ quadrimestre de 2021. Disponível em: www.univali.br/direitoepolitica - ISSN 1980-7791.

Como saliente Hugo Mazzilli:

A rigor, portanto, o Ministério Público pode existir seja num regime autoritário, seja num regime democrático; poderá ser forte tanto num, quanto noutro caso; porém, só será verdadeiramente independente num regime essencialmente democrático, porque não convém a governo totalitário algum que haja uma instituição, ainda que do próprio Estado, que possa tomar, com liberdade total, a decisão de acusar governantes ou de não processar os inimigos destes últimos.

Entre nós, a evolução do Ministério Público brasileiro não destoou do que vínhamos dizendo, como no último período ditatorial que vivemos. Mas, mesmo nesta última fase de opressão política (1964 a 1984), aos poucos começou a fazerse ouvir no próprio Ministério Público o clamor por uma instituição independente e voltada à defesa de valores democráticos. ${ }^{20}$

A promulgação da Lei Complementar 40/1981 e a frustação por parte do governo federal de outorgar o Ministério Público nacional a defesa da chamada "legalidade democrática" possibilitou um amplo debate no seio dos órgãos estaduais acerca do papel do Ministério Público na construção de uma sociedade. Para isso, defendiam que devia haver uma mudança de perfil institucional. Até então, a ideia que se fazia era de um Ministério Público à moda do parecerismo, isto é, um órgão que buscava em muito se assemelhar às funções do Magistrado, especialmente na práxis jurídica em que confeccionavam pareceres com os mesmos requisitos formais de uma sentença, atuando com uma independência em relação aos interesses dos incapazes que lembravam a atuação de um "minijuiz". ${ }^{21}$ Essas características afastaram o Ministério Público de um advogado da sociedade que, de certa forma, transformou-se em uma batalha de obtenção de vantagens e prerrogativas, à semelhança do Poder Judiciário, ainda hoje existente.

A mudança de perfil institucional para um órgão de controle, a doutrina do ombudsman não-eleito, deveu-se em muito ao protagonismo das associações

20 MAZZILI, Hugo Nigro. O Ministério Público e a defesa do regime democrático. Revista de Informação Legislativa, Brasília a. 35 n. 138 abr./jun. 1998, p. 65- 73. p. 66.

21 MACEDO JÚNIOR, Ronaldo Porto. A evolução institucional do ministério público brasileiro. In: SADEK, Maria Tereza (org.). Uma introdução ao estudo da justiça. Rio de Janeiro: Centro Edelstein de Pesquisas Sociais, p. 65-94, 2010. Disponível em: https://goo.gl/xw5DiR. acesso em 18 de abril de 2020. 
SOUZA CRUZ, Álvaro Ricardo de; NOGUEIRA, Bernardo G. B.; SILVA, Diogo Bacha e. Alteridade, differánce e ministério público em tempos de coronavírus. Revista Eletrônica Direito e Política, Programa de Pós-Graduação Stricto Sensu em Ciência Jurídica da UNIVALI, Itajaí, v.16, n.2, $2^{\circ}$ quadrimestre de 2021. Disponível em: www.univali.br/direitoepolitica - ISSN 1980-7791.

estaduais e nacionais do Ministério Público. A Carta de Curitiba, aprovada em 21 de junho de 1986, no $1^{\circ}$ Encontro Nacional de Procuradores-Gerais de Justiça e Presidentes das Associações Nacionais do Ministério Público, serviu como modelo de uma nova arquitetura constitucional do Ministério Público. Na Carta de Curitiba, o Ministério Público assume a defesa do regime democrático e do interesse público, com autonomia financeira e orçamentária, garantias de irredutibilidade, inamovibilidade e vitaliciedade própria da magistratura, adquirindo o status de um poder do Estado. ${ }^{22}$

O formato institucional aprovado na Carta de Curitiba foi encaminhado e incorporado à Comissão Afonso Arinos no texto inicial apresentado. $\mathrm{Na}$ Subcomissão do Poder Judiciário e do Ministério Público, o relato do Constituinte Paes Landim nos lembra o perfil institucional que então se adotaria:

Minha inquietação, aqui exposta, tem como escopo determinar ao Ministério Público, dentre suas atribuições, a de tutela dos interesses da sociedade, a de defensor do povo, digamos assim, a figura do ombudsman, como referiu V. Sa. Acho que ele poderia representar esse papel, ao contrário da criação do defensor do povo, do Ouvidor-Geral, fora das atribuições.

Essa atribuição deve ser inerente também ao Ministério Público, como fiscal da lei - custos legis - dos interesses da sociedade.

Perguntaria se não seria possível criar-se um Ministério Público ligado aos interesses específicos da sociedade, à defesa do regime democrático, da Constituição, das leis e, ao mesmo tempo, criar um serviço jurídico da União, como defensor específico da União.

Deste modo se valorizaria o papel do Ministério Público como defensor da sociedade, do sistema democrático. ${ }^{23}$

\footnotetext{
22 Texto da Carta disponível em: http://www.mazzilli.com.br/pages/informa/ccuritiba.pdf, acesso em 19 de abril de 2020 .

${ }^{23}$ Assembleia Nacional Constituinte. Ata da Subcomissão do Poder Judiciário e do Ministério Público, Discurso do Deputado Paes Landim. p. $25 . \quad$ Disponível em: http://www.senado.leg.br/publicacoes/anais/constituinte/3c Subcomissao Do Poder Judiciario.pdf , acesso em 19 de abril de 2020.
} 
SOUZA CRUZ, Álvaro Ricardo de; NOGUEIRA, Bernardo G. B.; SILVA, Diogo Bacha e. Alteridade, differánce e ministério público em tempos de coronavírus. Revista Eletrônica Direito e Política, Programa de Pós-Graduação Stricto Sensu em Ciência Jurídica da UNIVALI, Itajaí, v.16, n.2, $2^{\circ}$ quadrimestre de 2021. Disponível em: www.univali.br/direitoepolitica - ISSN 1980-7791.

Portanto, de uma instituição que ora integrava o Poder Judiciário, ora o Poder Executivo, a criação de um órgão específico de representação jurídica para o Poder Executivo, possibilitou que ao Ministério Público fosse conferido um status constitucional como órgão de atuação administrativa, essencial à administração da justiça, com garantias efetivas de poder de Estado.

A Constituição de 1988 conferiu, portanto, ao Ministério Público uma função substancial dentro da ordem constitucional que é de defesa da ordem jurídica e do regime democrático. Em certa medida, o tratamento valorativo pretendido pelo Constituinte foi a de um órgão cuja função permanente fosse a proteção do próprio regime democrático, sendo uma atividade mais profunda do que a legalidade democrática. Uma instituição cuja lei é ir além da lei e, por isso, função essencial à justiça. Justiça que, como sabemos, é uma aporia, uma transgressão da lei. ${ }^{24}$

Essa relação paradoxal da instituição da lei como transgressão da lei, coloca em evidência a importância da proteção da arquitetura democrática da Constituição de 1988 e o papel do Ministério Público como protetor, não exclusivo, do regime democrático. Aqui, obviamente, a democracia não é a perspectiva de uma técnica decisória da regra da maioria, nem mesmo uma forma de transmissão da vontade popular da regra da representação, assume sim uma perspectiva de conteúdo que vão para além dos arranjos institucionais.

O regime democrático aponta para a necessidade de articulação de igualdade e liberdade de uma minoria. ${ }^{25} \mathrm{~A}$ liberdade e igualdade, para o próprio regime do Estado Democrático de Direito, implica em uma cooriginalidade entre os direitos decorrentes da autonomia pública e privada. ${ }^{26}$ Não basta apenas um sentido formal

\footnotetext{
24 DERRIDA, Jacques. Force de Loi: Le "fondement mystique de I'autorité". Paris: Galilée, 2005.

25 Em Kelsen, se verifica como a democracia é uma condição procedimental destituída de valores:

""É a própria natureza que, exigindo liberdade, se rebela contra a sociedade. O peso da vontade alheia, imposto pela vida em sociedade, parece tanto mais opressivo quanto mais diretamente se exprime no homem o sentimento primitivo do próprio valor (...) Da idéia de que somos - idealmente - iguais, pode-se deduzir que ninguém deve mandar em ninguém. Mas a experiência ensina que, se quisermos ser realmente todos iguais, deveremos deixar-nos comandar. Por isso a ideologia política não renuncia a unir liberdade com igualdade. A síntese destes dois princípios é justamente a característica da democracia." (KELSEN, Hans. A Democracia. São Paulo: Martins Fontes, 2000. p. 27).

26 HABERMAS, Jürgen. Soberania popular como procedimento: um conceito normativo de espaço público. Novos Estudos Cebrap, no 26, março de 1990, p. 100-113.Cf, também: HABERMAS, Jürgen.
} 
SOUZA CRUZ, Álvaro Ricardo de; NOGUEIRA, Bernardo G. B.; SILVA, Diogo Bacha e. Alteridade, differánce e ministério público em tempos de coronavírus. Revista Eletrônica Direito e Política, Programa de Pós-Graduação Stricto Sensu em Ciência Jurídica da UNIVALI, Itajaí, v.16, n.2, $2^{\circ}$ quadrimestre de 2021. Disponível em: www.univali.br/direitoepolitica - ISSN 1980-7791.

de liberdade jurídica, mas a reunião de aspectos de condições mínimas de vida para a pessoa humana. ${ }^{27} \mathrm{~A}$ transgressão da legalidade é para a própria sobrevivência da legalidade. Em uma palavra, a violência fundadora é também instauradora.

A atuação do Ministério Público sob a égide da Constituição de 1988 foi apoiada de um lado de uma perspectiva ideológica pela doutrina da efetividade social e, de outro, como mecanismo de defesa do Estado Democrático de Direito pelo temor de retrocesso à ditadura durante a constituinte. Assim, na primeira perspectiva, ao Ministério Público caberia tornar efetiva as promessas não cumpridas do nosso constitucionalismo, já que a doutrina da efetividade social das normas jurídicas constitucionais teria se transformado, então, na grande aposta da comunidade jurídica progressista visando a concretização do modelo econômico de bem-estar preconizado na Constituição de 1988. De outro lado, seria preciso institucionalizar um órgão capaz de promover a promessa da própria garantia democrática, evitando um retorno aos ditames ditatoriais de um período em que, embora formalmente adornado como democrático, as práticas políticas do poder público restringiam os direitos fundamentais.

Sob este aspecto, a Constituição de 1988 articulou o Ministério Público sobre os princípios organizacionais da unidade, da indivisibilidade e da independência funcional (art. $127, \S 1^{\circ}$ ) que joga um papel relevante no seio da própria instituição e do próprio Estado Democrático de Direito.

Em primeiro lugar, a dogmática jurídica concebe a unidade e a indivisibilidade correlacionadas como a organização funcional pela qual os membros do Ministério Público pertencem um só órgão dirigido pelo Procurador-Geral e que, eventual substituição de um membro por outro, não tenha modificação na atuação do órgão, seja endoprocessualmente ou exoprocessualmente. ${ }^{28}$ De outro lado, e mesmo

Constitutional democracy: a paradoxical union of contradictory principles? Political Theory, v. 29, $\mathrm{n}$. 6, dec. 2001, p. 766-781.

27 AFONSO DA SILVA, José. Teoria do conhecimento constitucional. São Paulo: Malheiros, 2014. p. 679. Ver: NEUMANN, Franz. O conceito de liberdade política. Cadernos De Filosofia Alemã: Crítica e Modernidade, (22), 107-154.

28 Para tanto ver: FERNANDES, Bernardo Gonçalves. Curso de Direito Constitucional. $5^{a}$ ed. Salvador: m, 2013. p. 1015; MENDES, Gilmar; COELHO, Inocêncio; BRANCO, Paulo Gustavo Gonet. Curso de Direito Constitucional. 4a ed. São Paulo: Saraiva, 2009. p.1039. 
SOUZA CRUZ, Álvaro Ricardo de; NOGUEIRA, Bernardo G. B.; SILVA, Diogo Bacha e. Alteridade, differánce e ministério público em tempos de coronavírus. Revista Eletrônica Direito e Política, Programa de Pós-Graduação Stricto Sensu em Ciência Jurídica da UNIVALI, Itajaí, v.16, n.2, $2^{\circ}$ quadrimestre de 2021. Disponível em: www.univali.br/direitoepolitica - ISSN 1980-7791.

paradoxalmente, a atuação do Ministério Público se submete ao princípio da independência funcional pela qual cada um de seus membros é, ao mesmo tempo, autônomo e soberano em suas manifestações.

Como conciliar, portanto, tais aspectos quando há uma contradição evidente na prática jurídico-política? Ou seja, há casos em que, como demonstramos, a atuação do Procurador-Geral evidentemente contradiz a autonomia dos demais membros da instituição. De um lado, o Procurador-Geral que utiliza a unidade para centralizar as atividades e, de outro, os demais membros que buscam exercer sua consciência jurídica de proteção ao regime democrático.

Tais princípios podem ser utilizados tanto para a deflagração e aprofundamento de escala em um estado de exceção permanente na qual o direito é visto de acordo com aquilo que diz o soberano ${ }^{29}$ ou, então, para a proteção do regime democrático na defesa das minorias políticas.

\section{A RESPOSTA LOGOCÊNTRICA: ENTRE A RAZOABILIDADE E A PROIBIÇÃO DO EXCESSO}

O papel do Ministério Público, assim como sua autonomia e prerrogativas conquistadas na constituinte, dependerá em larga medida da legitimidade de sua atuação em prol da efetividade dos direitos fundamentais anunciados no bojo da Constituição de 1988 e estará a cargo da própria empreitada jurídico-política em substituição ao apoio político-econômico do Poder Executivo. ${ }^{30}$

A doutrina jurídica hegemônica busca uma resposta para sua atuação no âmbito daquilo que, a partir de uma crítica derridiana, é compreendida como logocentrismo. O pensamento metafísico platônico que acredita haver sempre "sentidos primeiros" ou tudo aquilo que se quer assentar como estabelecido e inquestionável. Entre o bem e o mal, o material e o imaterial, Phrónesis e Noesis,

\footnotetext{
${ }^{29}$ AGAMBEN, Giorgio. Estado de exceção. Trad. Iraci D. Poleti. 2. ed. São Paulo: Boitempo, 2007. 30 MACEDO JÚNIOR, Ronaldo Porto. A evolução institucional do ministério público brasileiro. In: SADEK, Maria Tereza (org.). Uma introdução ao estudo da justiça. Rio de Janeiro: Centro Edelstein de Pesquisas Sociais, p. 65-94, 2010. Disponível em: https://goo.gl/xw5DiR. acesso em 18 de abril de 2020.
} 
SOUZA CRUZ, Álvaro Ricardo de; NOGUEIRA, Bernardo G. B.; SILVA, Diogo Bacha e. Alteridade, differánce e ministério público em tempos de coronavírus. Revista Eletrônica Direito e Política, Programa de Pós-Graduação Stricto Sensu em Ciência Jurídica da UNIVALI, Itajaí, v.16, n.2, $2^{\circ}$ quadrimestre de 2021. Disponível em: www.univali.br/direitoepolitica - ISSN 1980-7791.

transcendente e imanente, céu e terra, essas dualidades constituem o âmago do pensamento logocêntrico e, portanto, da tradição jurídica hegemônica.

A exata medida que trabalha o dilema do Ministério Público entre a independência funcional e unidade institucional ganha corpo na interpretação e argumentação jurídica dessa tradição jurídica. Qual a medida que a independência avançaria sobre a unidade institucional? Como medir a independência? Existe alguém que seja independente dentro da lei? Há autonomia na lei? Ou a lei inventa a autonomia? É possível a unidade institucional sem a independência absoluta? Como ser um só e não o completamente outro?

Esses rastros deixados pelos questionamentos têm uma resposta que, ao menos na lógica da metafísica, seria segura a partir do conceito da razão prática, da phrónesis, da razoabilidade pelo legado grego.

Na República de Platão, livro IV, a temperança como virtude, como justiça, envolve uma ordem, uma harmonia que promove acordo entre os cidadãos: os fortes, os fracos e os medianos. A justiça da cidade deve ser um reflexo da justiça dos homens que tem dois princípios subjacentes à sua alma, o princípio racional e o irracional ou concupiscente. É o princípio racional que se identifica com a justiça, com a prudência e a temperança dos homens e da cidade. ${ }^{31}$

A prudência é um ato de julgar, isto é, uma decisão de pôr fim ao conflito, às incertezas decorrentes de uma certa urgência, de colocar termo em uma práxis sob o signo do trágico. ${ }^{32}$ Contudo, essa decisão do trágico só adquire validade na medida em que seja universalizável, que se constitua como lei. Esse traço entre a razoabilidade como decisão prudente voltada para o caso concreto e moldada a partir dele só é racional na medida de sua universalização. ${ }^{33}$

A razoabilidade jurídica, portanto, seria um ponto médio extraído a partir de um caso especial dos discursos práticos em geral, produzido a partir de condições

\footnotetext{
31 PLATÃO. A República. Trad. Carlos Alberto Nunes. 3a ed. Belém: EDUFPA, 2000.p. 215-216.

32 RICOUER, Paul. O justo. Vol. 2. São Paulo: WMFMartins Fontes, 2008. p. 62.

33 Eis, então, a aporia da interpretação/argumentação jurídica que perpassa desde autores como Alexy, Habermas, Dworkin quanto Savigny, Hart, Kelsen.
} 
SOUZA CRUZ, Álvaro Ricardo de; NOGUEIRA, Bernardo G. B.; SILVA, Diogo Bacha e. Alteridade, differánce e ministério público em tempos de coronavírus. Revista Eletrônica Direito e Política, Programa de Pós-Graduação Stricto Sensu em Ciência Jurídica da UNIVALI, Itajaí, v.16, n.2, $2^{\circ}$ quadrimestre de 2021. Disponível em: www.univali.br/direitoepolitica - ISSN 1980-7791.

procedimentais voltadas para a correção normativa dos seus enunciados ${ }^{34}$. A razão/racionalização entra aqui sob uma lógica universal na medida em que a ponderação possibilitaria o desvelar da resposta correta para aquele caso prático. ${ }^{35}$

Mesmo em Habermas, a distinção substancial entre discursos de fundamentação e aplicação, visam assegurar a participação democrática e, portanto, a universalização do processo de decisão singular. ${ }^{36} \mathrm{~A}$ razoabilidade é assegurada a partir de uma decisão voltada para o caso, mas que se justifica no discurso de fundamentação, universalizado pelo princípio da participação democrática.

Ora, a título de exemplificação, a razoabilidade incorporada à tradição decisória do Supremo Tribunal Federal, seja como princípio ou regra, acaba por, desconstituindo toda sua tradição, se fiando no pressuposto de uma verdade como certeza, certeza essa que nos é legada pela metafísica moderna de Kant e de Descartes. Ou seja, em uma palavra, por detrás da herança da phrónesis aristotélica, o logocentrismo promete a harmonia e o equilíbrio obtido pela razão humana. A aplicação do direito fica confiada à reta razão de um direito natural que, incorporado nos princípios, têm como exata medida a régua da ponderação. Escondem, portanto, a dialético do uno e do múltiplo com apoio em uma lógica analítica e transcendental, ambas incapazes de "prever" o "devir" dessa aporia. Ambas ignoram o cerne da política dentre essa lógica que colocam um "direito da força", do mais forte, do soberano como imposição sobre essa régua jurídica, bastando citar o patrimonialismo weberiano, a fachada da totalização levinasiana, o pulso da ideologia e dos batimentos das políticas.

Na atuação do Ministério Público, quando se estaria diante de um caso irrazoável de supressão dos direitos fundamentais aptos a fundamentarem a atuação em prol

\footnotetext{
${ }^{34}$ ALEXY, Robert. Teoria da Argumentação Jurídica: a teoria do discurso racional como teoria da fundamentação jurídica. $3^{a}$ Ed. Trad. Zilda Hutchinson Schild Silva. Rio de Janeiro: Forense, 2011. 35 ALEXY, Robert. Sobre duas justaposições: conceito e natureza, direito e filosofia. Alguns comentários sobre "pode haver uma teoria do direito?" de Joseph Raz. In: RAZ, Joseph; ALEXY, Robert; BULYGIN, Eugenio. Uma discussão sobre a teoria do direito. Trad. Sheila Stolz. São Paulo: Marcial Pons, 2013. p. 108.

36 HABERMAS, Jürgen. Facticidad y validez: sobre el derecho y el Estado Democratico de derecho em términos de teoria del discurso. 6a ed. Trad. Manuel Jiménez Redondo. Madri: Trotta, 2010.
} 
SOUZA CRUZ, Álvaro Ricardo de; NOGUEIRA, Bernardo G. B.; SILVA, Diogo Bacha e. Alteridade, differánce e ministério público em tempos de coronavírus. Revista Eletrônica Direito e Política, Programa de Pós-Graduação Stricto Sensu em Ciência Jurídica da UNIVALI, Itajaí, v.16, n.2, $2^{\circ}$ quadrimestre de 2021. Disponível em: www.univali.br/direitoepolitica - ISSN 1980-7791.

do oprimido? Deve a instituir falar uma só língua? Se há uma só língua, então como compatibilizar a independência de seus membros?

Sob a doutrina da efetividade, o direito pôde ser visto como um instrumento de transformação social. O Ministério Público deve assumir essa identidade de ativista em prol da efetividade dos direitos sociais. Mas, até qual ponto a unidade e a independência não jogam um papel que pode ser contrário ao estabelecimento e fortalecimento de um regime democrático.

Vejam o problema que agora fica claro em meio à pandemia do COVID-19. No tocante à unidade, a existência de Câmaras de Coordenação e Revisão, instituídas pela Lei Complementar 75/93, no âmbito do Ministério Público Federal, assim como grupos de trabalho afirmam a necessidade de uma política sistêmica para o enfrentamento de temáticas específicas, assim como o enfrentamento de situações excepcionais como as tragédias de Mariana e Brumadinho. Do mesmo modo, forças-tarefas que, cada vez mais, se tornam o novo normal, para operações de persecução criminal decorrente de crimes de lavagem de dinheiro e de corrupção exigem uma atuação coordenada. Qual a exata medida da razoabilidade para a preservação da independência funcional mantendo a unidade? Há algo matemático que nos indique quando um membro do Ministério Público estará falando em "nome próprio" ou por força da instituição? Essa lei do Ministério Público serve para manter a democracia? A democracia não é uma coexistência de liberdade do outro? O "nome próprio" não é este outro? Qual outro? O membro ou a sociedade?

De outro lado, a independência funcional garante aos membros da instituição um raio de ação livre de ingerências políticas face à chefia da instituição. De outro, também aqui um sempre outro, em um mundo cada vez mais globalizado, a ação errática de cada um dos membros, descolada de uma perspectiva concertada de ação conduz a instituição ao precipício da ineficiência. A independência, então, vem se tornando um convite "mudo" a ações visionárias que espelham a ideologia de cada membro. Uma faculdade que torna cada membro ensimesmado na crença de estarem "acima" da barganha política, fazendo com que cada um veja em si a corporificação da República. De outra banda, o abuso da unidade traz o risco de submeter a instituição aos caprichos do Chefe do Executivo, senhora da "caneta" 
SOUZA CRUZ, Álvaro Ricardo de; NOGUEIRA, Bernardo G. B.; SILVA, Diogo Bacha e. Alteridade, differánce e ministério público em tempos de coronavírus. Revista Eletrônica Direito e Política, Programa de Pós-Graduação Stricto Sensu em Ciência Jurídica da UNIVALI, Itajaí, v.16, n.2, $2^{\circ}$ quadrimestre de 2021. Disponível em: www.univali.br/direitoepolitica - ISSN 1980-7791.

que nomeia o chefe do Ministério Público. Logo, independência e a unidade forjam uma dobradiça entre arbítrio e democracia, entre o abuso e a omissão, entre o excesso e a desídia.

\section{PHÁRMAKON: O REMÉdio e O VENENO}

A unidade institucional e a independência funcional são construções logocêntricas. Seu desfazimento depende do entendimento de que, em si, são remédio e veneno ao Estado Democrático de Direito e à própria lei, à instituição como razões metafísicas. É preciso desconstruir seu significado à luz de uma outra razão, de um outro pensar, liberando-as das amarras da escritura, dos significados.

Derrida inicia um pensamento politicamente engajado dentro do qual não caberia mais dizer acerca dos pontos inaugurais, e, portanto, detentores da verdade; esse ato cometido afetaria em cheio um pensamento que se funda na presença e que se quer legitimar pela sua própria presença. Ou seja, afirmar a hipótese de que existe uma cadeia de significantes na linguagem é uma operação de profanação no próprio coração do pensamento abrindo a chance de novos usos, tornando a destinação a um fundamento primeiro o problema metafísico que impede no limite a vinda de quem vem - pois neste caso quem vem estaria vindo a partir e em direção a esse fundamento que tudo sustenta, ou seja, não haveria um pensamento do Outro, uma vez que encerrado nessa dimensão de verdade, que a tudo comanda, confere um sentido, e, portanto, enclausura na presença de si.

É importante estarmos assentes que a dimensão de razão e conhecimento e logos aqui nessa volta comparecem para mostrar como Derrida entende que a escritura sempre teve uma participação suplementar, rebaixada, distante da verdade ou atuando como uma encenação. Isso é necessário para entendermos o fundo do pensamento derridiano. Neste sentido, o primeiro topos socrático sinaliza duas questões: quando ele coloca o mito em seu lugar, que não seria o lugar devido ao saber e ao ócio e isso de maneira teórica e também espacial, ouçamos Sócrates:

Fedro: Não prestei atenção a isso mas, por Zeus, diz-me Sócrates, acreditas nessa lenda, achas que é verdadeira? 
SOUZA CRUZ, Álvaro Ricardo de; NOGUEIRA, Bernardo G. B.; SILVA, Diogo Bacha e. Alteridade, differánce e ministério público em tempos de coronavírus. Revista Eletrônica Direito e Política, Programa de Pós-Graduação Stricto Sensu em Ciência Jurídica da UNIVALI, Itajaí, v.16, n.2, $2^{\circ}$ quadrimestre de 2021. Disponível em: www.univali.br/direitoepolitica - ISSN 1980-7791.

Sócrates: Se eu fosse um incrédulo como os doutores, não seria um homem extravagante; além disso, afirmaria que ela tinha sido arremessada dos rochedos próximos por um vento boreal, enquanto brincava com Farmacéia, e que das própria circunstâncias de sua morte nasceu a lenda de seu rapto por Bóreas. Por mim, caro Fedro, qualquer uma dessas explicações tem a sua validade, mas para isso torna-se necessário mito génio, muito trabalho e não encontramos nisso a felicidade. Seria necessário interpretar seguidamente a imagem dos Hipocentauros, depois a de Quimera e, então, seríamos submergidos por uma enorme multidão de Gorgónias ou de Pégasos, por outras criaturas multitudinárias e bizarras, e por criaturas inimagináveis e por monstros legendários! Se, por incredulidade, se conceder a cada uma destas figuras a medida da verossimilhança fazendo uso, para tanto, de não sei que grosseira sabedoria, nem sequer teremos um momento de ócio! Ora, eu não dedico meu ócio a explicações desse género, e fica sabendo por que motivo meu caro: ainda não consegui, até agora, conforme recomenda a inscrição délfica, conhecer-me a mim mesmo (PLATÃO, 229d - 230)

Portanto, esse um primeiro momento no qual Sócrates nos dá a ver em que consistiria um momento de ócio que enquanto momento de construção e reflexão estaria bastante distante do que os saberes mitológicos poderiam produzir. Neles não haveria, portanto, lugar para a sabedoria, para o conhecimento filosófico, criando assim essa hierarquia, que se escutarmos Derrida, e o faremos, parece estar intimamente ligada à própria estrutura de construção de um pensamento que se fia na palavra, no logos, e que necessita, portanto, de alguém que o diga: um "pai" que esteja a dizer da verdade. Dizer a verdade, pois, aquilo que será escrito é secundário e afastado da verdade, restaria apenas como um local incompatível com ela. Seguindo com Derrida, ele questiona se acaso esse momento inicial do diálogo no qual é invocada Farmacéia seria meramente casual; a interpretação que Derrida nos traz é a de que a virgem ao brincar com Farmaceia, aquela que administra os remédios, leva-a a morrer pelo seu envenenamento ${ }^{37}$. E, logo adiante no decorrer do diálogo, Sócrates diz a Fedro que ele o havia levado

\footnotetext{
37 Farmacéia (Pharmákeia) é também um nome comum que significa administração do phármakon, da droga: do remédio e/ou veneno. "Envenenamento" não era o sentido menos corrente de "farmacéia". Antifon deixou-nos o logograma de uma "acusação de envenenamento contra uma madrasta" (Pharmakeías katá tês meutruiâs). Por seu jogo, Farmacéia levou à morte a pureza virginal e um íntimo impenetrado. (DERRIDA, Jacques. A farmácia de Platão. 3. ed. São Paulo: Editora Iluminuras, 2005. p. 14)
} 
SOUZA CRUZ, Álvaro Ricardo de; NOGUEIRA, Bernardo G. B.; SILVA, Diogo Bacha e. Alteridade, differánce e ministério público em tempos de coronavírus. Revista Eletrônica Direito e Política, Programa de Pós-Graduação Stricto Sensu em Ciência Jurídica da UNIVALI, Itajaí, v.16, n.2, $2^{\circ}$ quadrimestre de 2021. Disponível em: www.univali.br/direitoepolitica - ISSN 1980-7791.

para um lugar que não seria o habitat comum, para fora da cidade, o filósofo então teria sido seduzido pelo poder do phármakon que ele já alude como sendo os escritos que Fedro trazia consigo.

Assim, a palavra phármakon ${ }^{38}$ instala-se à nossa volta dando a ver o deslocamento espacial que havíamos aludido, ou seja, Sócrates envenenado pelo phármakon, seduzido ${ }^{39}$ por ele, e é muito importante ver o encanto que está por detrás desse termo, que por ser um indecidível, em si mesmo guarda seu sim e seu não, mais um nem nem ${ }^{40}$ se quisermos pensar junto da economia derridiana.

\section{Phármakon que encanta, que faz desviar, que leva-nos entorpecidos ao longe, no} caso de Sócrates, para fora de sua condição sagrada de homem da polis ${ }^{41}$. Mas o

38 Esse encanto, essa "medicina", esse filtro, ao mesmo tempo remédio e veneno, já se introduz no
corpo do discurso com toda sua ambivalência. Esse encanto, essa virtude da fascinação, essa
potência de feitiço podem ser - alternada e simultaneamente - benéficas e maléficas. O phármakon
seria uma substância, com tudo o que esta palavra possa conotar, no que diz respeito a sua matéria,
de virtudes ocultas, de profundidade críptica recusando sua ambivalência à análise, preparando,
desde então, o espaço da alquimia, caso não devamos seguir mais longe reconhecendo-a como a
própria anti-substância: o que resiste a todo filosofema, excedendo-o indefinidamente como não-
identidade, não-essência, não substância, e fornecendo-Ihe, por isso mesmo, a inesgotável
adversidade de seu fundo e de sua ausência de fundo. (DERRIDA, Jacques. A farmácia de Platão. 3. ed. São Paulo: Editora Iluminuras, 2005. p. 14)

39 "Seduzir" quer também dizer "desviar" (seducere), "atrair para fora do caminho recto". (DERRIDA, Jacques. A escritura e a diferença. Trad. Maria Beatriz M. N. Da Silva, Pedro Leite Lopes e Pérola de Carvalho. São Paulo: Perspectiva, 2009, p. 68)

40 Assim a filósofa argentina Mónica Cragnolini definiu a desconstrução. Para ela, a desconstrução é um constante tremor e " 'solicitando' o edifício da metafisica, se experimenta esse tremor dos muros que, desde sempre, desde a suposta origem, 'já' estão se descontruindo". E é este movimento que faz com que se trema diante de um pensamento como este, que trema e se tema, pois um pensamento do "nem/nem" assusta, por nos levar ao lugar indecidível do "entre". Diz ela: "Frnte à metafísica oposicional, caracterizada pelo binarismo, o desconstrucionismo se acha situado no 'entre' das oposições: nem verdade nem falsidade, nem presença nem ausência, mas sim 'entre'. O 'entre' está designando um âmbito de oscilação do pensar (...) O 'entre' não é um novo lugar, mas é nãolugar, impossibilidade de assentamento, constante perigo..." (HADDOCK-LOBO, Rafael. Derrida e o labirinto de inscrições. Porto. Alegre, RS: editora Zouk,2008, p. 38)

41 ...haveria, então, essa figuração do homem como "animal político" ou como vivente político (politikon zôon", segundo a fórmula ao mesmo tempo tão conhecida e tão enigmática de Aristóteles em sua Política (Livro I, 125a 3); é evidente, nos diz, então Aristóteles, que a polis faz parte das coisas da natureza (tôn phusei) e que o homem é por natureza um vivente político (...) de onde ele conclui, depois de ter, contrariamente ao que se ouve ou se lê por vezes, insistido muito, no mesmo texto, nas mesmas páginas, e, ainda, um pouco antes, sobre viver e sobre a vida como zên, e não como bios, sobre o eu zên, bem viver não também teremos que retornar a esse ponto, de onde ele conclui, então, que um ser sem cidade, apolis, um ser apolítico é por natureza e não por acaso (...), ou bem pior (...), ou bem melhor que o homem, superior ao homem (...) - o que marca bem o fato de que a politicidade, o ser político do vivente denominado homem é um ponto médio entre esses dois outros viventes que são a besta e o deus que, cada um à sua maneira, seriam "apolíticos" (...) então, essa figuração do homem como "animal político" ou como "vivente político", mas também uma dupla e contraditória figuração (...) por um lado, superior, em sua soberania mesma, à besta da qual ele se torna mestre, que ele escraviza, domina, domestica ou mata, de modo que a soberania consiste em se elevar a uma posição acima do animal e se apropriar dele, dispor de sua vida, mas, 
SOUZA CRUZ, Álvaro Ricardo de; NOGUEIRA, Bernardo G. B.; SILVA, Diogo Bacha e. Alteridade, differánce e ministério público em tempos de coronavírus. Revista Eletrônica Direito e Política, Programa de Pós-Graduação Stricto Sensu em Ciência Jurídica da UNIVALI, Itajaí, v.16, n.2, $2^{\circ}$ quadrimestre de 2021. Disponível em: www.univali.br/direitoepolitica - ISSN 1980-7791.

mesmo phármakon que leva para fora da cidade é também o remédio para a cura. Phármakon que retira o filósofo de si, que o faz deambular por locais outros. Importa percebermos que a inserção do termo phármakon no diálogo revela também a instância para a qual Derrida nos conduz, também ele inebriado? Mostra que na mesma dimensão do mito, que não se dá à altura do saber da cidade, na mesma dimensão de algo que é e não é - o phármakon -, os escritos sobre o amor carregados por Fedro levam Sócrates a um outro lugar.

Sair da cidade acompanhado pelo phármakon, ação ao mesmo tempo relatada por um caminhar na direção de um local no qual supostamente Sócrates ouviria Fedro, porém, ao mesmo passo, pelo mesmo passo, acompanhados do remédio que encantara Sócrates, como o amor, o phármakon traz segredos, ele não garantirá a cura, posto que age sempre nessa dimensão dúbia, entre a salvação e a morte, pelo encanto. Neste sentido é que já poderíamos pensar junto de Derrida sobre o limite, sobre a morte, pois para essa autor "nada morre", ou seja, no limite/morte ${ }^{42}$, na margem, há um momento de renascimento, de procura e espera pelo que vem, o que nos lança ao pensamento da différance; porém, indicar que nada morre é dizer que nada é propriamente, mas que os significantes se reenviam e carreiam consigo sempre a sua própria (de)formação, isso impediria a morte, o

por outro lado (contraditoriamente), figuração do homem político, e notadamente do Estado soberano como animalidade, até mesmo como bestialidade (...) seja uma bestialidade normal, seja uma bestialidade monstruosa e ela mesma mitológica e fabulosa. O homem político superior à animalidade e homem político como animalidade (...) por que a soberania política, o soberano, o Estado ou o povo, são figuras tanto quando aquilo que se eleva, pela lei da razão, acima da besta, acima da vida natural do animal, e tanto quanto (ou simultaneamente) a manifestação da bestialidade ou da animalidade humana, dito de outro modo, da naturalidade humana? (DERRIDA, Jacques. A besta e o soberano. Vol. 1. (2001-2002). Rio de Janeiro: Via verita, 2016, pp. 50-52)

42 No entanto, um trabalho como este não pode ser guiado, como normalmente é pela filosofia, por um desejo de ultrapassar ou de romper com a metafísica. Para o filósofo, nada morre, e, desse modo, não se pode decretar o fim de nada. Antes, como vimos, ao dizer que tenta se manter sempre no limite do discurso filosófico, a palavra limite é utilizada justamente no lugar do termo "morte". O que há é uma transgressão da metafísica: o que não significa que se deve e modo algum pensar essa transgressão como uma instalação em um "além da metafísica", nem mesmo "além da linguagem", pois, segundo o próprio, "mesmo nas agressões ou nas transgressões, utilizamo-nos de um código ao qual a metafísica está irredutivelmente ligada, de tal sorte que todo gesto transgressivo volta a nos encerrar no interior da metafísica - precisamente por ela no servir de ponto de apoio" (DERRIDA, Jacques. Mal de Arquivo: uma impressão freudiana. Trad. Claudia de Moraes Rego. Rio de Janeiro: Relume Dumará, 2001.p. 18-19) No entanto, deve haver um certo tipo de transgressão, qual seja, a que faça justiça ao próprio movimento interno do pensamento - o eu Derrida vem chama de Desconstrução. Ela se dá no interior mesmo do pensamento, não de um fora: não se habita jamais outro lugar e, por essa razão, esse tipo de transgressão implica somente o fato de o limite ou as margens do pensamento estarem sempre em movimento. (HADDOCK-LOBO, Rafael. Derrida e o labirinto de inscrições. Porto. Alegre: editora Zouk2008, p. 24) 
SOUZA CRUZ, Álvaro Ricardo de; NOGUEIRA, Bernardo G. B.; SILVA, Diogo Bacha e. Alteridade, differánce e ministério público em tempos de coronavírus. Revista Eletrônica Direito e Política, Programa de Pós-Graduação Stricto Sensu em Ciência Jurídica da UNIVALI, Itajaí, v.16, n.2, $2^{\circ}$ quadrimestre de 2021. Disponível em: www.univali.br/direitoepolitica - ISSN 1980-7791.

limite, que serão sempre reenviados a outros significantes revelando ou deixando vir o que os conceitos ou pares opostos escondem.

Haverá sempre um termo que comanda o outro, o seu outro no par oposto, e isso mostra a necessidade da desconstrução que operaria nesta ordem de pares opostos, que nunca são ingênuos, haverá a existência de um que determina a subserviência do outro ou ao outro. ${ }^{43}$

Quem deve ser subserviente a quem: o membro do Ministério Público? o Ministério Público? O Procurador-Geral da República? À Lei? À Constituição? À democracia? Independência ou unidade? Diferença ou unidade? A unidade do diferente e o diferente da unidade, eis a relação paradoxal.

No presente, essa Instituição mesmo e sua lei, que nasce sob a promessa da efetividade social e da proteção ao Estado Democrático de Direito, possibilitou a que cada um de seus membros, levados pelo canto das sereias, impusesse seus valores, autoproclamados republicanos, em detrimento a essa mesma lei (unidade institucional). Acordos de delação premiada e de leniência, termos de ajustamento de condutas, investigações criminais, denúncias foram todas direcionadas contra inimigos eleitos em nome da independência funcional. Essa disputa de poder e, sobretudo, monopólio por ser O guardião da lei passam a ficar "fora" da instituição e de sua lei, sobretudo do Estado Democrático de Direito e dessa promessa. O excesso de independência funcional é seu veneno. Em tempos de pandemia, para matar o vírus, o remédio mata o hospedeiro. Isto é, em nome da democracia, seus membros agem "fora" dela, matam-na. Eis, aqui, quando há a dose do veneno.

43 Como acontece em qualquer situação de imposição, e a estratégia desconstrucionista é particularmente sensível a este respeito, a reivindicação dos direitos da parte de quem sofre a imposição pode simplesmente não ocorrer por algum tempo e, quando ocorre, pode muito bem ser ignorada, desprezada, reprimida ou rejeitada, ou mesma causar indignação, mas tal reivindicação não deixa de permanecer, contudo, como algo incontornável. É neste sentido que se coloca a necessidade de um momento ou, como diz Derrida, de uma fase de inversão no interior do trabalho desconstrucionista (...) Mas, por outro lado, este momento de inversão é estruturalmente inseparável de um momento de deslocamento com relação ao sistema a que antes pertenciam os termos de uma dada oposição conceitual. Estes últimos, uma vez deslocados para outro lugar, vão inscrever um outro sistema, um outro registro discursivo. Já se pode antever, portanto, que não se trata de uma pura e simples inversão, nem tampouco do aprofundamento de um único e mesmo sistema conceitual. Re-situados em um outro registro, segundo outros critérios, não se pode pensar que, ainda assim, se trate dos mesmo termos. (DUQUE-ESTRADA, Paulo César. Às Margens - a Propósito de Derrida. Rio de Janeiro:Loyola,2002, pp. 11-12) 
SOUZA CRUZ, Álvaro Ricardo de; NOGUEIRA, Bernardo G. B.; SILVA, Diogo Bacha e. Alteridade, differánce e ministério público em tempos de coronavírus. Revista Eletrônica Direito e Política, Programa de Pós-Graduação Stricto Sensu em Ciência Jurídica da UNIVALI, Itajaí, v.16, n.2, $2^{\circ}$ quadrimestre de 2021. Disponível em: www.univali.br/direitoepolitica - ISSN 1980-7791.

Mas há tempos vivemos um sono conservador e as instituições agem sob esse viés, essa temporalidade kairológica, logocêntrica, que não permite para além dessa dualidade entre independência funcional ou unidade institucional em nome de ações políticas que, em seus extremos, significam o veneno para o Estado Democrático de Direito.

Pensemos, portanto, no Rosto dos atores. O Procurador-Geral da República, Augusto Aras, nomeado fora da lista tríplice, arquiva procedimentos investigatórios abertos contra o Presidente da República, centraliza as ações de controle em relação ao governo federal, mantém-se subserviente à lógica conservadora em nome da unidade institucional e, ainda, para a proteção do Guardião da Lei, o Presidente da República.

Essa relação é escancarada diante do sujeito do direito e do soberano ou, para ilustrarmos, um kafkaniano "diante da lei". ${ }^{44} \mathrm{O}$ homem do campo que está diante

\footnotetext{
44 Diante da lei. Franz Kafka
}

Diante da lei, encontra-se um guardião da porta. Um homem do campo vai até ele e pede para entrar na lei. Mas o guardião diz que no momento não é possível conceder-lhe a entrada. O homem então reflete e indaga se mais tarde Ihe será permitido entrar. "É possível", diz o guardião, "mas agora não". Uma vez que o acesso para a lei se encontra como sempre aberto e o guardião se afasta para o lado, o homem se abaixa para ver o interior. Ao perceber isso, o guardião ri e diz: "Se o atrai dessa forma, tente então entrar, apesar de minha proibição. Observe apenas o seguinte: sou poderoso. E sou somente o mais inferior dos guardiães. Todavia, cada sala tem o seu, um mais poderoso do que o outro. Nem mesmo eu posso mais suportar a visão do terceiro". O homem do campo não esperava por tais dificuldades; é claro que a lei devia ser sempre acessível a todos, pensa ele, mas agora ao observar mais atentamente o guardião em seu casaco de pele, com o grande nariz pontiagudo, a longa barba tártara, fina e escura, acaba decidindo que é melhor aguardar, até obter a permissão para a entrada. O guardião Ihe dá um banquinho e deixa-o sentar-se ao lado da porta. Ali fica ele durante dias e anos. Faz várias tentativas para ter sua entrada admitida, cansando o guardião com seus pedidos.

Este o submete com frequência a pequenos interrogatórios, perguntando sobre sua terra natal e diversas outras coisas, mas são perguntas sem interesse, como as que costumam fazer os fidalgos; e, finalmente, o guardião repete sempre que ainda não pode deixá-lo entrar. Tendo preparado muitas coisas para a viagem, o homem dispende tudo, por mais valioso que seja, para subornar o guardião. Embora aceite tudo, o outro acaba sempre por declarar: "Apenas aceito para que você não pense que perdeu a ocasião de fazer algo". O homem observa o guardião durante muitos anos quase ininterruptamente. Esquece-se dos outros guardiães, parecendo-Ihe que aquele primeiro era o único obstáculo para entrar na lei. Ele amaldiçoa sua falta de sorte, nos primeiros anos desrespeitosamente alto; mais tarde, à medida que vai ficando velho, apenas resmunga consigo mesmo. Torna-se infantil, e, à força de examinar durante anos atentamente o guardião, acaba por conhecer também as pulgas da gola de seu casaco, pedindo que estas o ajudem a fazê-lo mudar de ideia. Finalmente sua vista enfraquece, mas ele não sabe se de fato escureceu em torno ou se apenas seus olhos o enganam. Porém, agora na escuridão, ele se dá conta de um brilho inextinguível que irrompe da porta da lei. Já não lhe sobra muito tempo de vida. Antes de morrer, as experiências do tempo que lá levou convergem em sua cabeça numa pergunta, a qual até o momento ainda não havia feito ao guardião. Acena para ele, visto que não consegue mais erguer seu corpo cada vez mais enrijecido. O guardião precisa se inclinar bastante, pois a diferença de tamanho aumentou muito, de modo desfavorável ao 
SOUZA CRUZ, Álvaro Ricardo de; NOGUEIRA, Bernardo G. B.; SILVA, Diogo Bacha e. Alteridade, differánce e ministério público em tempos de coronavírus. Revista Eletrônica Direito e Política, Programa de Pós-Graduação Stricto Sensu em Ciência Jurídica da UNIVALI, Itajaí, v.16, n.2, $2^{\circ}$ quadrimestre de 2021. Disponível em: www.univali.br/direitoepolitica - ISSN 1980-7791.

da lei, de frente à lei, em um posição marcadamente de sujeição diante do guardião que, no entanto, interdita o acesso à lei. Nem mesmo o próprio guardião está na presença da lei que também está separado da lei por essa relação de interdição. Há sempre um guardião mais forte, chegando a tal ponto que o "terceiro" é inacessível mesmo ao guardião.

Este homem do campo representa bem o caráter proibido/interdito da lei como nome e atributo. Essa é a relação paradoxal de seu acontecimento. É ela mesma proibida, interditada, um local interdito. Não se alcança a lei, apenas se alcança seu guardião, com seus representantes e, de outro lado, estes são interditores e seus mensageiros. Nós devemos permanecer ignorantes de quem ou o quê ou onde é a lei, nem saber quem é, como se apresenta, de onde vem e como fala. É isso que importa na lei. ${ }^{45}$

Essa lei que é interditada ao homem do campo é a mesma que a funda, essa lei que difere seu julgamento, cuja essência é a própria lei que nunca se dá a ver, também não pode ser determinada, subtraindo-se à essência do ser que seria a presença. Assim, esse homem do campo não seria, pela própria ausência da lei, um sujeito à margem da lei, um fora da lei?

Se, então, o homem do campo está fora da lei, além da lei, ele é, no finito, mas também no infinito, um pré-julgado. Esse infinito que nos traz um Rosto.

Deborah Duprat, Procuradora Federal dos Direitos do Cidadão do Ministério Público Federal, cujo mandato neste órgão expirará em maio de 2020, a-presenta esse homem do campo diante da lei. Sua atuação na pandemia foi de emitir nota técnica aos demais membros do Ministério Público que eventual relaxamento nas medidas de distanciamento, sem motivação suficiente e fundamentada dos órgãos de proteção à saúde, geraria, em tese, atos de improbidade administrativas dos

homem. "O que ainda quer saber agora?", indaga, "você é insaciável". "Todo mundo aspira à lei", diz o homem, "como então se explica que, em todos esses anos, ninguém além de mim solicitou admissão?" O guardião pressente que o homem já está chegando ao fim e, para ainda alcançar sua audição deficiente, ele berra: "Ninguém mais podia ser admitido aqui, pois esta entrada se destinava somente a você. Agora vou e a tranco".(NASCIMENTO, Evandro. O tempo e o espaço da tradução. Revista Letras, Curitiba, ufpr, n. 95 123-142, jan./jun. 2017).

45 DERRIDA, Jacques. Before the Law.in: Acts of Literature. Ed. Derek Attridge. London: Routledge, 1992. p. 203-204. 
SOUZA CRUZ, Álvaro Ricardo de; NOGUEIRA, Bernardo G. B.; SILVA, Diogo Bacha e. Alteridade, differánce e ministério público em tempos de coronavírus. Revista Eletrônica Direito e Política, Programa de Pós-Graduação Stricto Sensu em Ciência Jurídica da UNIVALI, Itajaí, v.16, n.2, $2^{\circ}$ quadrimestre de 2021. Disponível em: www.univali.br/direitoepolitica - ISSN 1980-7791.

gestores públicos. Ademais, seu histórico de atuação no combate à tortura, assim como em prol do reconhecimento e da efetividade dos direitos dos "fora da lei", os marginalizados, destacam uma ação que fortalece o regime democrático e a própria Instituição ou a lei da instituição.

\section{CONSIDERAÇÕES FINAIS}

Devemos compreender que a história do Ministério Público no ordenamento jurídico é, ao mesmo tempo, uma história institucional e também biográfica. É uma história de vida e de morte de seus membros, uma biografia que fica inscrita em cada parecer, em cada recurso, em cada petição produzida pelos seus membros. Preservar a memória e a história institucional do Ministério Público é preservar a biografia de seus membros que, arduamente, lutaram pelo espaço constitucionalmente adquirido com a Constituição de 1988.

Mais, preservar a memória e a história institucional do Ministério Público significa contemplar seus membros com condições e possibilidades para a proteção daqueles que conferem sentido à existência institucional. Preservar e conservar o papel do Ministério Público no Estado Democrático de Direito é também mostrar o Rosto daqueles que lutaram e lutam pela defesa dos vulnerabilizados, marginalizados e violentados pelo sistema dominante.

Assim como o Ministério Público historicamente saiu da margem da divisão de poderes para desestabilizar o centro da dinâmica institucional do Estado de Direito, é preciso que, mesmo e principalmente em momentos de crises políticas, consiga operar sob uma lógica da differánce, do diferente, do outro.

Preservar e conservar a memória do Ministério Público é homenagear e fazer jus ao Rosto de Déborah Duprat pela sua atuação em prol da defesa do regime democrático e contra o sistema político-econômico de opressão que fulmina os direitos fundamentais e sociais conquistados em meio a sangue daqueles que lutaram bravamente contra a ditadura civil-militar. 
SOUZA CRUZ, Álvaro Ricardo de; NOGUEIRA, Bernardo G. B.; SILVA, Diogo Bacha e. Alteridade, differánce e ministério público em tempos de coronavírus. Revista Eletrônica Direito e Política, Programa de Pós-Graduação Stricto Sensu em Ciência Jurídica da UNIVALI, Itajaí, v.16, n.2, $2^{\circ}$ quadrimestre de 2021. Disponível em: www.univali.br/direitoepolitica - ISSN 1980-7791.

\section{REFERÊNCIAS DAS FONTES CITADAS}

AFONSO DA SILVA, José. Teoria do conhecimento constitucional. São Paulo: Malheiros, 2014. p. 679.

AGAMBEN, Giorgio. Estado de exceção. Trad. Iraci D. Poleti. 2. ed. São Paulo: Boitempo, 2007.

ALEXY, Robert. Sobre duas justaposições: conceito e natureza, direito e filosofia. Alguns comentários sobre "pode haver uma teoria do direito?" de Joseph Raz. In: RAZ, Joseph; ALEXY, Robert; BULYGIN, Eugenio. Uma discussão sobre a teoria do direito. Trad. Sheila Stolz. São Paulo: Marcial Pons, 2013.

ALEXY, Robert. Teoria da Argumentação Jurídica: a teoria do discurso racional como teoria da fundamentação jurídica. $3^{a}$ Ed. Trad. Zilda Hutchinson Schild Silva. Rio de Janeiro: Forense, 2011.

BENJAMIN, Walter. Sobre o conceito da história. In: Magia, técnica, arte e política: ensaios sobre literatura e história da cultura. 8a ed. São Paulo: Brasiliense, 2012.

CAPUTO, John. Religion Without Religion: The Prayers and Tears. London: Routledge, 2002.

DERRIDA, Jacques. A escritura e a diferença. Trad. Maria Beatriz M. N. Da Silva, Pedro Leite Lopes e Pérola de Carvalho. São Paulo: Perspectiva, 2009.

DERRIDA, Jacques. A escritura e a diferença. Trad. Maria Beatriz M. N. Da Silva, Pedro Leite Lopes e Pérola de Carvalho. São Paulo: Perspectiva, 2009.

DERRIDA, Jacques. A farmácia de Platão. 3. ed. São Paulo: Editora Iluminuras, 2005.

DERRIDA, Jacques. Before the Law.in: Acts of Literature. Ed. Derek Attridge. London: Routledge, 1992.

DERRIDA, Jacques. Essa estranha instituição chamada literatura. Belo Horizonte: Editora UFMG, 2014.

DERRIDA, Jacques. Mal de Arquivo: uma impressão freudiana. Trad. Claudia de Moraes Rego. Rio de Janeiro: Relume Dumará, 2001.

DUQUE-ESTRADA, Paulo César. Às Margens - a Propósito de Derrida. Rio de Janeiro: Loyola, 2002.

FERNANDES, Bernardo Gonçalves. Curso de Direito Constitucional. 5a ed. Salvador: $\mathrm{m}, 2013$.

HABERMAS, Jürgen. Constitutional democracy: a paradoxical union of contradictory principles? Political Theory, v. 29, n. 6, dec. 2001, p. 766-781. 
SOUZA CRUZ, Álvaro Ricardo de; NOGUEIRA, Bernardo G. B.; SILVA, Diogo Bacha e. Alteridade, differánce e ministério público em tempos de coronavírus. Revista Eletrônica Direito e Política, Programa de Pós-Graduação Stricto Sensu em Ciência Jurídica da UNIVALI, Itajaí, v.16, n.2, $2^{\circ}$ quadrimestre de 2021. Disponível em: www.univali.br/direitoepolitica - ISSN 1980-7791.

HABERMAS, Jürgen. Facticidad y validez: sobre el derecho y el Estado Democratico de derecho em términos de teoria del discurso. 6a ed. Trad. Manuel Jiménez Redondo. Madri: Trotta, 2010.

HABERMAS, Jürgen. Soberania popular como procedimento: um conceito normativo de espaço público. Novos Estudos Cebrap, no 26, março de 1990, p. 100-113.

HADDOCK-LOBO, Rafael. Derrida e o labirinto de inscrições. Porto. Alegre, RS: editora Zouk,2008.

KELSEN, Hans. A Democracia. São Paulo: Martins Fontes, 2000.

LÉVINAS, Emmanuel. Totalidade e infinito. Lisboa: Edições 70, 2000.

MACEDO JÚNIOR, Ronaldo Porto. A evolução institucional do ministério público brasileiro. In: SADEK, Maria Tereza (org.). Uma introdução ao estudo da justiça. Rio de Janeiro: Centro Edelstein de Pesquisas Sociais, p. 65-94, 2010. Disponível em: https://goo.gl/xw5DiR. acesso em 18 de abril de 2020.

MAZZILI, Hugo Nigro. O Ministério Público e a defesa do regime democrático. Revista de Informação Legislativa, Brasília a. 35 n. 138 abr./jun. 1998, p. 65- 73.

MENDES, Gilmar; COELHO, Inocêncio; BRANCO, Paulo Gustavo Gonet. Curso de Direito Constitucional. $4^{a}$ ed. São Paulo: Saraiva, 2009.

NASCIMENTO, Evandro. O tempo e o espaço da tradução. Revista Letras, Curitiba, ufpr, n. 95 123-142, jan./jun. 2017.

NEUMANN, Franz. O conceito de liberdade política. Cadernos De Filosofia Alemã: Crítica e Modernidade, (22), 107-154.

PLATÃO. A República. Trad. Carlos Alberto Nunes. 3a ed. Belém: EDUFPA, 2000.

RICOUER, Paul. O justo. Vol. 2. São Paulo: WMF Martins Fontes, 2008.

SAID, Edward. Orientalismo: o oriente como invenção do ocidente. Trad. Tomás Rosa Bueno. São Paulo: Companhia das Letras, 1990.

RECEBIDO EM: ABR/2020

APROVADO EM: JUN/2021 